\title{
PENDETEKSI MANAJEMEN LABA: BEBAN PAJAK TANGGUHAN ATAU KUALITAS AKRUAL PAJAK PENGHASILAN?
}

\author{
Maharani Dhian Kusumawati \\ Universitas Kristen Duta Wacana \\ maharanidhian@staff.ukdw.ac.id
}

\begin{abstract}
Abstrak: Pendeteksi Manajemen Laba: Beban Pajak Tangguhan atau Kualitas Akrual Pajak Penghasilan? Penelitian ini bertujuan untuk menguji perbedaan kemampuan beban pajak tangguhan dan kualitas akrual pajak untuk mendeteksi perilaku manajemen laba dalam menghindari kerugian. Manajemen laba merupakan variabel dependen yang diukur menggunakan scaled earnings changes dalam kondisi perusahaan melakukan manajemen laba untuk menghindari kerugian yang digunakan oleh Phillips et al. (2003) dan dimodifikasi oleh Suranggane (2007) sesuai dengan kondisi di Indonesia. Beban pajak tangguhan dan kualitas akrual pajak penghasilan merupakan variabel independen. Beban pajak tangguhan diperoleh dari laporan laba rugi, sedangkan kualitas akrual pajak penghasilan diukur dengan model regresi yang diperkenalkan oleh Choudary et al. (2016). Sampel yang digunakan sejumlah 31 perusahaan manufaktur yang terdaftar di BEI pada tahun 2013-2017 dan memenuhi kriteria yang ditetapkan. Regresi logistik digunakan untuk menguji hipotesis dan menemukan hasil bahwa kemampuan kualitas akrual pajak dalam pendeteksian keterjadian manajemen laba untuk menghindari kerugian lebih superior dibanding beban pajak tangguhan. Semakin tinggi kualitas akrual pajak penghasilan suatu perusahaan, maka semakin rendah kemungkinan perusahaan melakukan manajemen laba untuk menghindari kerugian.
\end{abstract}

Kata kunci: Beban Pajak Tangguhan, Kualitas Akrual Pajak Penghasilan, Manajemen Laba

Abstract: Earnings Management Detector: Deferred Tax Expense or Income Tax Accrual Quality? This study aims to investigates differences in the ability of deferred tax expense and income tax accrual quality to detect earnings management behavior in avoiding losses. Earnings management is the dependent variable that is measured using scaled earnings changes in the condition of companies doing earnings management to avoid losses used by Phillips et al. (2003) and modified by Suranggane (2007) according to conditions in Indonesia. Deferred tax expense and the income tax accrual quality are the independent variable. Deferred tax expense is obtained from the income statement, while the income tax accrual quality is measured by a regression model introduced by Choudary et al. (2016). The samples used were 31 manufacturing companies listed on the Indonesia Stock Exchange in 20132017 and met the specified criteria. Logistic regression was used to tested the hyphotesis and found that the ability of income tax accrual quality in detecting the earnings management to avoid losses is superior to deferred tax expense. The higher of income tax accrual quality, the lower the possibility of the company doing earnings management to avoid losses.

Keywords: Deferred Tax Expense, Income Tax Accrual Quality, Earnings Management

\section{PENDAHULUAN}

Manajemen laba berkaitan dengan kebijakan yang dapat dilakukan oleh manajemen. Phillips et al., (2003) menyatakan bahwa manajer mempunyai kebijakan yang lebih luas di bawah prinsip akuntansi dibanding di bawah peraturan perpajakan. Standar akuntansi memberi beberapa alternatif metode dan kewenangan untuk mengestimasi, yang dapat dipilih dan dilakukan oleh manajemen. Sedangkan peraturan perpajakan diatur lebih mengikat dibanding standar akutansi. Hal ini dikarenakan adanya perbedaan antara standar 


\section{Nominal: Barometer Riset Akuntansi dan Manajemen}

P-ISSN: 2303-2065 E-ISSN: 2502-5430

Volume 9 No 1 (2020)

akuntansi dan peraturan pajak yang akan menimbulkan perbedaan permanen dan perbedaan temporer.

Perbedaan permanen terjadi karena ada pendapatan dan beban menurut akuntansi yang tidak dapat diakui menurut peraturan perpajakan. Contohnya saja Undang-Undang No. 36 Tahun 2008 tentang Pajak Penghasilan yang mengatur mengenai penghasilan sebagai objek pajak (pasal 4 (1)), penghasilan yang dikenai pajak bersifat final (pasal 4 (2)), penghasilan yang dikecualikan dari objek pajak (pasal 4 (3)), biaya yang boleh dikurangkan (pasal 6), dan biaya yang tidak boleh dikurangkan (pasal 9). Perbedaan tetap ini akan terus ada selama tetap ada perbedaan antara standar akuntansi dan peraturan perpajakan.

Perbedaan temporer terjadi karena adanya perbedaan akuntansi dan perpajakan yang sifatnya temporer. Salah satu penyebab perbedaan temporer adalah adanya perbedaan estimasi. Misalnya saja dalam perhitungan penyusutan aset tetap. Standar akuntansi mengijinkan perusahaan untuk memilih menggunakan metode garis lurus, saldo menurun, atau unit produksi dengan estimasi umur ekonomis sesuai kebijakan manajemen. Sedangkan peraturan perpajakan sudah mengatur dalam UU No. 36 tahun 2008 bahwa metode penyusutan yang diijinkan hanya garis lurus dan saldo menurun dengan estimasi umur ekonomis sesuai dengan kelompok aset dalam undangundang tersebut. Perbedaan temporer ini menyebabkan perbedaan alokasi setiap tahun, tetapi akan sama di tahun terakhir. Adanya perbedaan alokasi ini menimbulkan adanya aset pajak tangguhan dan beban pajak tangguhan. Beban pajak tangguhan merupakan komponen dari beban pajak suatu perusahaan dan merefleksikan pengaruh pajak karena perbedaan temporer antara laba akuntansi dan laba menurut perpajakan (laba fiskal) yang berasal dari akrual untuk pendapatan dan beban yang mempengaruhi laba akuntansi dan laba fiskal, tetapi pada periode yang berbeda (Phillips et al., 2003).

Laba akuntansi diartikan dalam PSAK 46 sebagai laba rugi tanpa potongan beban pajak. Beban pajak tangguhan dicatat pada laporan laba rugi dengan liabilitas pajak tangguhan dicatat dalam laporan posisi keuangan (Ikatan Akuntan Indonesia, 2014). Phillips et al. (2003) menyebutkan bahwa beban pajak tangguhan dapat digunakan untuk mengetahui adanya perilaku manajemen laba dalam rangka untuk menghindari penurunan laba, menghindari kerugian, dan menghindari gagal mencapai target laba para analis. Ketiga hal ini adalah earnings thresholds atau benchmark yang ingin dicapai manajemen. Salah satu alasan manajemen ingin memenuhi earnings thresholds ini adalah karena earnings atau laba dipandang sebagai indikator kesuksesan 


\section{Nominal: Barometer Riset Akuntansi dan Manajemen}

P-ISSN: 2303-2065 E-ISSN: 2502-5430

Volume 9 No 1 (2020)

kinerja suatu perusahaan (Holland and Ramsay, 2003).

Penelitian Phillips et al. (2003) menemukan bahwa beban pajak tangguhan terbukti dapat mendeteksi perilaku manajemen laba untuk menghindari penurunan laba dan menghindari kerugian. Yuliati (2005) dan Sumomba \& Hutomo (2012) juga meneliti hal yang sama di Indonesia dan menemukan bahwa beban pajak tangguhan berpengaruh positif terhadap perilaku manajemen laba untuk menghindari kerugian. Manajemen laba untuk menghindari kerugian adalah suatu perilaku oportunistik yang dilakukan oleh manajemen perusahaan untuk menghindari pelaporan kerugian. Hal ini dilakukan untuk menurunkan biaya yang dihadapi perusahaan pada transaksi dengan stakeholder, karena sesuai dengan transaction cost theory, jika perusahaan melaporkan rugi akan menghadapi biaya transaksi yang tinggi dengan stakeholder dibanding perusahaan yang melaporkan laba (Burgstahler and Dichev, 1997).

Selain beban pajak tangguhan, Phillips et al., (2003) juga menguji komponen akrual untuk mendeteksi manajemen laba untuk menghindari kerugian. Penelitian tersebut menemukan bahwa beban pajak tangguhan lebih akurat dalam mendeteksi perilaku manajemen laba untuk menghindari kerugian dibanding total akrual, model abnormal akrual modified jones, maupun model forward-looking abnormal accrual. Yuliati (2005) meneliti kembali dengan sampel seluruh perusahaan Indonesia yang terdaftar di BEJ pada tahun 1999-2002 dan menemukan bahwa baik beban pajak tangguhan maupun akrual berpengaruh positif terhadap probabilitas perusahaan melakukan manajemen laba untuk menghindari kerugian. Namun, beban pajak tangguhan memiliki tingkat keyakinan yang lebih tinggi dibanding model discretionary accrual. Suranggane (2007) juga menemukan bahwa akrual dengan model dicretionary accrual dari modified Jones yang terjadi di perusahaan manufaktur yang terdaftar di BEJ tahun 2003-2005 berpengaruh terhadap manajemen laba. Berdasarkan beberapa penelitian, akrual ditemukan memiliki pengaruh yang lebih rendah dibanding beban pajak tangguhan untuk mendeteksi manajemen laba. Phillips et al. (2003) berargumen bahwa kesalahan pengukuran akrual yang digunakan untuk mendeteksi manajemen laba dapat dikurangi dengan berfokus pada beban pajak tangguhan, daripada dengan memisahkan akrual menjadi komponen normal dan abnormal. Pernyataan ini didukung oleh hasil penelitian Phillips et al. (2003), Yuliati (2005), dan Suranggane (2007) yang menemukan superioritas beban pajak 
Nominal: Barometer Riset Akuntansi dan Manajemen

P-ISSN: 2303-2065 E-ISSN: 2502-5430

Volume 9 No 1 (2020)

tangguhan dibanding akrual untuk kokoh untuk mendeteksi keterjadian mendeteksi manajemen laba.

Keunggulan beban pajak tangguhan dibanding akrual untuk mendeteksi laba disanggah oleh Yuliati (2005) dalam keterbatasan penelitian Yuliati (2005) menyatakan bahwa dalam penelitian yang menggunakan beban pajak tangguhan sebagai pendeteksi manajemen laba didasari pada argumen bahwa seluruh beban pajak tangguhan merupakan komponen kebijakan manajemen. Padahal pada realitanya, kemungkinan beban pajak tangguhan murni berasal dari kegiatan operasional perusahaan. Oleh karena itu, penelitian ini mengajukan pengukuran baru yang dapat digunakan untuk mendeteksi manajemen laba dan masih melibatkan komponen akrual yaitu kualitas akrual pajak (tax accrual quality) yang diperkenalkan oleh Choudary et al. (2016). Ukuran ini menangkap variasi pemetaan pajak penghasilan akrual (income tax accrual) menjadi pajak penghasilan yang terkait kas (income tax-related cash flows). Semakin rendah variasi mengindikasikan semakin baik kualitas akrual pajak (Choudhary et al., 2016). Di Indonesia, kualitas akrual pajak dapat diterapkan untuk melihat variasi pemetaan pajak penghasilan akrual menjadi pajak penghasilan yang dibayarkan secara tunai dan tercatat dalam laporan arus kas. Kualitas akrual pajak ini diprediksi dapat menjadi alat yang lebih

\section{KAJIAN LITERATUR}

\section{Beban Pajak Tangguhan}

Beban pajak tangguhan merupakan komponen penyusunan beban pajak penghasilan pada laporan laba rugi. PSAK 46 merinci bahwa beban pajak terdiri dari pajak kini dan pajak tangguhan, baik berupa penghasilan maupun beban (Ikatan Akuntan Indonesia, 2014). Pajak kini dihitung dari laba kena pajak yang diperoleh dari rekonsiliasi fiskal dikalikan dengan tarif pajak yang berlaku. Pajak kini ini sama dengan pajak yang dibayar ke aparat perpajakan dan dilaporkan pada SPT.

Pajak tangguhan terjadi karena adanya perbedaan temporer antara standar akuntansi dan peraturan perpajakan (Ikatan Akuntan 


\section{Nominal: Barometer Riset Akuntansi dan Manajemen}

P-ISSN: 2303-2065 E-ISSN: 2502-5430

Volume 9 No 1 (2020)

Indonesia, 2014). Beda temporer ini sering disebut juga sebagai beda waktu karena perbedaan jumlah yang dilaporkan antara catatan akuntansi dan perpajakan hanya karena perbedaan waktu pengakuan pendapatan ataupun beban, yang pada akhirnya akan sama (Waluyo, 2012). Beda temporer ini kemudian menyebabkan perbedaan antara laba akuntansi dan laba fiskal. Apabila laba fiskal lebih besar dari laba akuntansi, maka pajak yang dibayar lebih besar dari beban pajak yang tercatat oleh akuntansi sehingga muncul aset pajak tangguhan. Aset pajak tangguhan timbul di sisi debet dan dicatat dalam laporan posisi keuangan, sedangkan di sisi kredit muncul manfaat pajak tangguhan pada laporan laba rugi karena termasuk pendapatan bagi perusahaan.

Sebaliknya, apabila pada satu periode, laba fiskal lebih kecil dari laba akuntansi, maka pajak yang dibayar lebih kecil dari beban pajak yang tercatat oleh akuntansi sehingga muncul liabilitas pajak tangguhan. Liabilitas pajak tangguhan terletak di sisi kredit dan dicatat dalam laporan posisi keuangan, sedangkan di sisi debet timbul beban pajak tangguhan yang dicatat pada laporan laba rugi. Menurut PSAK 46 paragraf 5, liabilitas pajak tangguhan merupakan kewajiban atas pajak penghasilan yang harus dibayar perusahaan pada tahun berikutnya (Ikatan Akuntan Indonesia, 2014).

\section{Kualitas Akrual Pajak}

Pencatatan akuntansi menggunakan dasar akrual yaitu dengan cara mencatat transaksi pada periode terjadinya transaksi. Akrual berperan untuk menggeser atau menyesuaikan pengakuan arus kas selama beberapa periode waktu sehingga angka yang sudah disesuaikan, yaitu earnings, menjadi ukuran yang lebih baik untuk kinerja perusahaan (Dechow \& Dichev, 2002). Menurut Dechow and Dichev (2002) akrual dan arus kas merupakan komponen dari earnings. Sedangkan Francis et al. (2006) lebih spesifik menyatakan bahwa net income sama dengan arus kas dari aktivitas operasi ditambah total akrual. Berdasarkan Francis et al. (2006) ini, dapat disimpulkan bahwa untuk memperoleh total akrual maka perusahaan dapat mengurangi net income dengan arus kas dari aktivitas operasi. Akrual dalam suatu perusahaan dikatakan berkualitas buruk jika estimation error dari akrual ini besar (Dechow \& Dichev, 2002). Akrual dikatakan berkualitas baik jika sebagain besar komponen akrual dapat dipetakan ke dalam arus kas operasi masa lalu, masa kini, dan masa yang akan datang, sehingga menghasilkan estimation error yang kecil (Dechow \& Dichev, 2002).

Persamaan Dechow and Dichev (2002) ini dimodifikasi oleh Choudhary et al. (2016) 


\section{Nominal: Barometer Riset Akuntansi dan Manajemen \\ P-ISSN: 2303-2065 E-ISSN: 2502-5430 \\ Volume 9 No 1 (2020)}

untuk memperoleh income tax accrual maka mengurangi beban pajak penghasilan (income tax expense) dengan pajak penghasilan yang terkait kas (income taxrelated cash flows) atau pajak penghasilan yang sudah dibayar secara tunai (cash taxes paid). Persamaan modifikasian ini yang selanjutnya digunakan untuk mendefinisikan kualitas akrual pajak penghasilan. Choudhary et al. (2016) mendefinisikan kualitas akrual pajak penghasilan sebagai variasi pemetaan pajak penghasilan akrual (income tax accrual) menjadi pajak penghasilan yang terkait kas (income taxrelated cash flows). Semakin rendah variasi mengindikasikan semakin baik kualitas akrual pajak penghasilan (Choudhary et al., 2016). Variasi ditangkap melalui estimation error atau residual.

\section{Manajemen Laba}

Manajemen laba terjadi ketika manajer menggunakan judgement dalam pelaporan keuangan dan dalam peyusunan transaksi untuk memanipulasi laporan keuangan, mengelabui beberapa pemangku kepentingan mengenai kinerja ekonomi perusahaan, dan atau mempengaruhi keputusan kontraktual berdasarkan praktik akuntansi yang dilaporkan (Healy and Wahlen, 1999). Manajemen laba dapat dilakukan melalui manipulasi akrual tanpa konsekuensi langsung ke arus kas yang disebut dengan manipulasi akrual maupun manipulasi aktivitias riil selama satu tahun untuk mencapai target earnings tertentu (Roychowdhury, 2006). Holland and Ramsay (2003) menyebutkan dua target earnings atau earnings thresholds yang ingin dicapai manajer yaitu untuk menghindari pelaporan rugi atau penurunan earnings. Menurut Holland and Ramsay (2003) terdapat 3 alasan yang mendasari. Pertama, earnings digunakan sebagai indikator kesuksesan suatu bisnis dan ditempatkan sebagai tujuan strategis perusahaan pada urutan pertama. Kedua, adanya motivasi untuk meningkatkan harga saham. Ketiga, adanya perjanjian kontraktual antara perusahaan dengan stakeholder yang mendorong perusahaan untuk tetap stabil dan reliabel dengan tetap menjaga earnings sesuai target.

Manajemen laba untuk menghindari kerugian pertama kali diperkenalkan oleh Burgstahler and Dichev (1997). Dalam penelitian ini, Burgstahler and Dichev (1997) menyebutkan dua teori yang mendasari perilaku manajemen laba ini. Teori pertama yaitu transaction cost theory yang menyatakan bahwa perusahaan yang melaporkan rugi akan menanggung biaya transaksi yang tinggi dengan stakeholder dibanding perusahaan yang melaporkan laba. Oleh karena itu, manajer menghindari pelaporan kerugian untuk menurunkan biaya yang dihadapi perusahaan pada transaksi 


\section{Nominal: Barometer Riset Akuntansi dan Manajemen}

P-ISSN: 2303-2065 E-ISSN: 2502-5430

Volume 9 No 1 (2020)

dengan stakeholder. Teori kedua ialah prospect theory yang menyatakan bahwa pengambil keputusan mengambil nilai dari kondisi laba dan rugi pada suatu titik referensi, dibanding dari suatu nilai yang absolut. Sehingga perusahaan cenderung untuk mengalihkan dari kerugian absolut menjadi kerugian relatif. Holland and Ramsay (2003) menyebutkan bahwa menurut prospect theory, laba terbesar dapat terjadi ketika terjadi peralihan dari kerugian relatif atau absolut menjadi laba.

\section{Pengembangan Hipotesis}

Pajak tangguhan terjadi karena perbedaan temporer antara standar akuntansi dan peraturan perpajakan. Perbedaan aturan ini menimbulkan perbedaan antara laba akuntansi dan laba fiskal. Beban pajak tangguhan muncul saat laba fiskal lebih kecil daripada laba akuntansi, sehingga pajak yang dibayar dan dilaporkan kepada pemerintah lebih kecil dari beban pajak yang tercatat oleh akuntansi. Phillips et al. (2003) menemukan bahwa manajer perusahaan melakukan manajemen laba dengan cara meningkatkan laba akuntansi melalui pemilihan kebijakan yang diijinkan oleh standar akuntansi sehingga tidak mempengaruhi laba fiskal. Peningkatan laba akuntansi yang tidak diimbangi denga peningkatan laba fiskal akan menimbulkan beban pajak tangguhan menjadi lebih tinggi. Hal ini dapat terjadi karena beban pajak menurut perhitungan akuntansi lebih besar daripada pajak yang dibayarkan kepada pemerintah. Pillips et al. (2003) menyatakan bahwa beban pajak tangguhan dapat digunakan untuk mendeteksi adanya perilaku manajemen laba di suatu perusahaan. Salah satu motivasi manajer meningkatkan laba akuntansi melalui manajemen laba dan tidak diimbangi dengan peningkatan laba fiskal yaitu untuk menghindari pelaporan kerugian. Manajer termotivasi untuk meningkatkan laba akuntansi supaya memuaskan para stakeholder yang membaca laporan keuangan perusahaan. Misalnya, dengan laporan laba rugi yang menunjukkan kondisi laba yang meningkat dari periode sebelumnya, sehingga investor tertarik untuk membeli saham perusahaan. Peningkatan laba akuntansi yang menguntungkan perusahaan ini tidak disertai peningkatan laba fiskal, sehingga besaran pajak penghasilan yang harus dibayarkan kepada pemerintah tetap sama seperti saat tidak terjadi manajemen laba. Oleh karena itu, diprediksi bahwa beban pajak tangguhan dapat digunakan untuk mendeteksi keterjadian manajemen laba sehingga dibangun hipotesis:

H1: Beban pajak tangguhan berpengaruh positif dengan terjadinya manajemen laba untuk menghindari rugi 
Perilaku manajemen laba yang dilakukan perusahaan untuk menghindari pelaporan kerugian diduga dapat dideteksi melalui kualitas akrual pajak penghasilan. Kualitas pajak penghasilan dapat digunakan untuk melihat pemetaan pajak penghasilan akrual menjadi pajak penghasilan yang dibayarkan secara tunai dan tercatat dalam laporan arus kas. Semakin tinggi kualitas akrual pajak penghasilan, berarti semakin banyak akrual pajak penghasilan yang dapat dipetakan menjadi kas. Hal ini menunjukkan bahwa terbentuknya akrual pajak penghasilan dalam perusahaan semata-mata karena perbedaan waktu pencatatan (beda temporer) antara akuntansi dan perpajakan, bukan karena manipulasi yang dilakukan oleh manajemen. Berdasarkan pemikiran tersebut maka diprediksi bahwa semakin tinggi kualitas akrual pajak penghasilan yang digambarkan dengan semakin rendah variasi (estimation error) yang timbul, menunjukkan rendahnya tingkat keterjadian manajemen laba dalam perusahaan. Oleh karena itu, dibangun hipotesis:

H2: Kualitas akrual pajak penghasilan berpengaruh negatif dengan terjadinya manajemen laba untuk menghindari rugi.

\section{METODE PENELITIAN}

\section{Jenis dan Sumber Data}

Jenis penelitian ini ialah penelitian eksplanatori yang akan mencari hubungan antara variabel. Data yang digunakan dalam penelitian ini berupa data sekunder yang diperoleh dari laporan keuangan tahunan perusahaan yang dipublikasikan pada Bursa Efek Indonesia pada tahun 2012-2018.

\section{Populasi dan Sampel}

Populasi dalam penelitian ini yaitu seluruh perusahaan manufaktur yang terdaftar di Bursa Efek Indonesia (BEI). Sampel diambil dari populasi dengan menggunakan metode purposive sampling. Kriteria yang digunakan untuk mengambil sampel yaitu:

a. Perusahaan terdaftar di BEI pada periode 2012-2018. Periode efektif yang digunakan untuk penelitian yaitu 2013-2017. Data tahun 2012 dan 2018 diperlukan dalam perhitungan variabel dalam penelitian ini.

b. Perusahaan melaporkan adanya beban pajak tangguhan dalam laporan laba rugi.

\section{Definisi Operasional Variabel}

Variabel dependen yang digunakan dalam penelitian ini ialah manajemen laba, sedangkan variabel independen terdiri dari beban pajak tangguhan dan kualitas akrual pajak.

a. Manajemen laba (EM) 
Manajemen laba diukur menggunakan scaled earnings changes dalam kondisi perusahaan melakukan manajemen laba untuk menghindari kerugian yang digunakan oleh Phillips et al. (2003) dan dimodifikasi oleh Suranggane (2007) supaya sesuai dengan kondisi di Indonesia.

$$
\mathrm{EM}_{\mathrm{it}}=\mathrm{NI}_{\mathrm{it}} / \mathrm{MVE}_{\mathrm{it}-1}
$$

$$
\begin{aligned}
& \text { Keterangan: } \\
& \mathrm{EM}= \text { earnings management } \\
& \text { atau manajemen laba. } \text { Berdasarkan } \\
& \text { Suranggane }(2007), \\
& \text { jika } 0<\mathrm{EM} \leq 0,06, \\
& \text { maka perusahaan } \\
& \text { termasuk small profit } \\
& \text { firm dan diberi nilai 1. } \\
& \text { Sedangkan jika -0,09 } \\
& \leq \text { EM < 0, maka } \\
& \text { perusahaan termasuk } \\
& \text { small loss firm dan } \\
& \text { diberi nilai 0. } \\
&= \text { net income atau laba } \\
& \text { bersih } \\
& \text { market value of equity }
\end{aligned}
$$

b. Beban pajak tangguhan (deffered tax expense / DTE)

Beban pajak tangguhan menggunakan akun beban pajak tangguhan yang ada di laporan laba rugi diskala (dibagi) dengan total aset tahun t-1. Pembagian ini sesuai dengan Phillips et al. (2003).

c. Kualitas akrual pajak (tax accrual quality/TaxAQ)
Kualitas akrual pajak menggunakan model regresi yang diperkenalkan oleh Choudary et al. (2016) yaitu:

$\operatorname{TaxAcc}_{\text {it }}=\beta_{0}+\beta_{1} \mathrm{CTP}_{\mathrm{it}-1}+\beta_{2} \mathrm{CTP}_{\text {it }}+$ $\beta_{3} \mathrm{CTP}_{\mathrm{it}+1}+\varepsilon_{\mathrm{it}}$

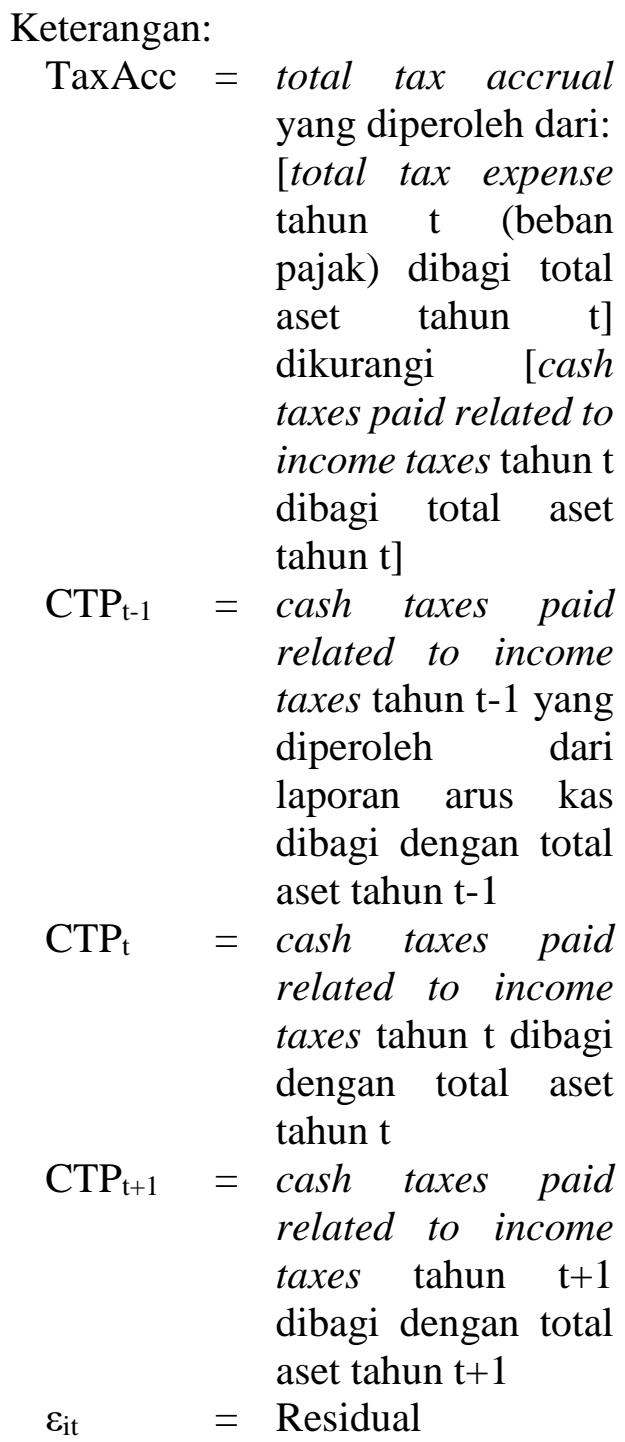

Residual dari persamaan tersebut menangkap tax accrual yang tidak dapat dipetakan menjadi arus kas yang terkait. Kualitas akrual pajak (TaxAQ) diperoleh dari residual dikalikan dengan (-1), yang berarti semakin 
tinggi TaxAQ maka semakin baik kualitas akrual pajak perusahaan.

\section{Teknik Analisis Data}

Persamaan yang digunakan untuk menguji hipotesis penelitian yaitu persamaan regresi logistik berikut ini:

$$
1-\mathrm{EM}_{\mathrm{it}}=\beta_{0}+\beta_{1} \mathrm{DTE}_{\mathrm{it}}+\beta_{2} \operatorname{TaxAQ}_{\text {it }}+\varepsilon_{\mathrm{it}}
$$

\section{Keterangan:}

$$
\begin{aligned}
\mathrm{EM} & =\text { manajemen laba } \\
\mathrm{CTP}_{\mathrm{t}-1} & =\begin{array}{l}
\text { deffered tax expense/ beban } \\
\text { pajak tangguhan }
\end{array} \\
\mathrm{CTP}_{\mathrm{t}} & =\begin{array}{l}
\text { tax accrual quality/ kualitas } \\
\text { akrual pajak }
\end{array} \\
\varepsilon_{\mathrm{it}} & =\text { Residual }
\end{aligned}
$$

\section{HASIL PENELITIAN DAN PEMBAHASAN}

\section{Proses Pengambilan Sampel}

Sampel dalam penelitian ini diambil dari populasi yaitu perusahaan manufaktur yang terdaftar di BEI dengan beberapa syarat. Berikut proses pengambilan sampel:

Tabel 1 Proses Pengambilan Sampel

\begin{tabular}{llc}
\hline No. & \multicolumn{1}{c}{ Kriteria } & $\begin{array}{c}\text { Jumlah } \\
\text { sampel }\end{array}$ \\
\hline 1 & $\begin{array}{l}\text { Perusahaan terdaftar di } \\
\text { BEI pada periode 2012- }\end{array}$ & \\
& 2018 \\
2 & $\begin{array}{l}\text { Perusahaan melaporkan } \\
\text { adanya beban pajak }\end{array}$ \\
& tangguhan dalam laporan \\
& laba rugi pada periode \\
& 2013-2017 \\
3 & $\begin{array}{l}\text { Perusahaan } \\
\text { mempublikasikan laporan } \\
\text { keuangan pada periode } \\
\text { 2012-2018 }\end{array}$ \\
\hline
\end{tabular}

\begin{tabular}{llc}
\hline No. & \multicolumn{1}{c}{ Kriteria } & $\begin{array}{c}\text { Jumlah } \\
\text { sampel }\end{array}$ \\
\hline 4 & $\begin{array}{l}\text { Perusahaan memiliki } \\
\text { nilai variabel EM yang }\end{array}$ & \\
& memenuhi kriteria small \\
& profit firm $(0<$ EM $\leq$ \\
& $0,06)$ dan small loss firm \\
& $(-0,09 \leq$ EM $<0)$ \\
& Sampel akhir & \\
\hline
\end{tabular}

Sumber: Hasil olah data (2019)

\section{Statistik Deskriptif}

Statistik deskriptif digunakan untuk menampilkan data setiap variabel. Variabel dependen yaitu earnings management (EM), sedangkan variabel dependen ialah beban pajak tangguhan (DTE) dan kualitas akrual pajak (TaxAQ). Dari 31 sampel yang diperoleh terdiri dari 19 small profit firm dan 12 small loss firm berdasarkan nilai variabel EM.

Tabel 2 Statistik Deskriptif Kelompok Small Profit Firm

\begin{tabular}{lcrcr}
\hline & $\mathbf{N}$ & \multicolumn{1}{c}{ Min } & Max & \multicolumn{1}{c}{ Mean } \\
\hline DTE & 19 & 0,00000 & 0,00908 & 0,0024442 \\
TaxAQ & 19 & $-0,05305$ & 0,01533 & $-0,0049358$ \\
\hline
\end{tabular}

Sumber: Hasil olah data (2019)

Tabel 3 Statistik Deskriptif Kelompok Small Loss Firm

\begin{tabular}{lcccc}
\hline & N & Min & Max & Mean \\
\hline DTE & 12 & 0,00050 & 0,01309 & 0,0051117 \\
TaxAQ & 12 & 0,00081 & 0,01715 & 0,0078133 \\
\hline \multicolumn{5}{c}{ Sumber: Hasil olah data (2019) }
\end{tabular}

Berdasarkan tabel 2 dan 3 dapat dibandingkan dua hal. Pertama, variabel beban pajak tangguhan (DTE) untuk kelompok small profit firm memiliki nilai yang lebih rendah dibanding kelompok small loss firm. Hal ini dapat dilihat dari range nilai 
minimal hingga maksimal, serta nilai mean. Artinya, perusahaan yang menghindari kerugian sehingga berusaha memperoleh laba walau sedikit (small profit), justru terbukti membukukan beban pajak tangguhan lebih kecil dibanding perusahaan yang benar-benar menderita kerugian (small loss). Kedua, variabel kualitas akrual pajak (TaxAQ) untuk kelompok small profit firm lebih rendah dibanding kelompok small loss firm. Terbukti dari range nilai minimal hingga maksimal. Small profit firm memiliki range dari $-0,05305$ hingga 0,01533 , sedangkan small loss firm memiliki range nilai yang lebih tinggi yaitu antara 0,00081 hingga 0,01715 .

\section{Pengujian Hipotesis}

Hipotesis penelitian diuji menggunakan regresi logistik karena variabel dependen yaitu EM merupakan variabel dummy. EM akan bernilai 1 jika sampel termasuk kategori small profit firm dan diberi nilai 0 jika sampel termasuk kategori small loss firm. Regresi logistik memerlukan beberapa tahap pengujian. Pertama, menilai model fit berdasarkan fungsi likelihood yang ditampilan pada tabel 4.

Nilai -2LL mengalami penurunan sebesar 13,715 dan signifikan pada level 0,01 , sehingga disimpulkan bahwa model yang dihipotesikan fit dengan data.

Tabel 4 Perbandingan Nilai -2Log

Likelihood

\begin{tabular}{cc}
\hline Block Number & Nilai -2LL \\
\hline 0 & 41,381 \\
1 & 27,666 \\
\hline
\end{tabular}

Sumber: Hasil olah data (2019)

Kedua, melihat nilai $\mathrm{R}$ square melalui Nagelkerke $\mathrm{R}$ Square. Berdasarkan pengujian diperoleh nilai Nagelkerke $\mathrm{R}$ Square sebesar 0,485 yang berarti variabilitas variabel EM dapat dijelaskan melalui variabilitas varibel DTE dan TaxAQ sebesar $48,5 \%$.

Ketiga, menilai kecocokan data empiris dengan model melalui nilai Hosmer and Lemeshow's Goodness of Fit yang ditampilkan pada tabel 5 berikut:

Tabel 5 Hasil Hosmer and Lemeshow Test

\begin{tabular}{ccc}
\hline Chi-Square & df & Sig \\
\hline 3,233 & 8 &, 919 \\
\hline Sumber: Hasil olah data $(2019)$
\end{tabular}

Nilai Hosmer and Lemeshow sebesar 3,233 dengan tingkat signifikansi 0,919 . Nilai signifikansi ini di atas 0,05 , artinya model mampu memprediksi nilai observasinya atau data empiris cocok dengan model.

Setelah melalui 3 tahap di atas maka dapat diperoleh hasil regresi logsitik untuk persamaan yang telah dibangun sebelumnya sebagai berikut:

Tabel 6 Hasil Uji Signifikansi

\begin{tabular}{lcc}
\hline \multicolumn{1}{c}{ Variabel } & B & Sig. \\
\hline DTE & $-310,245$ & 0,066 \\
TaxAQ & $-132,814$ & 0,024 \\
\multicolumn{2}{l}{ Sumber: Hasil olah data (2019) }
\end{tabular}


Berdasarkan hasil pengujian hipotesis di atas diperoleh hasil bahwa variabel DTE memiliki nilai signifikansi 0,066 yang terletak di bawah 0,10 dengan nilai beta 310,245. Hasil ini berarti beban pajak tangguhan berpengaruh negatif dengan terjadinya manajemen laba untuk menghindari rugi, sehingga H1 tidak terdukung. Sedangkan variabel TaxAQ memiliki nilai signifikansi 0,024 yang berada di bawah 0,10 dengan koefisien beta bernilai $-132,814$. Artinya kualitas akrual pajak berpengaruh negatif dengan terjadinya manajemen laba untuk menghindari rugi, sehingga $\mathrm{H} 2$ didukung.

\section{Pembahasan}

Hasil pengujian hipotesis pertama menunjukkan beban pajak tangguhan berpengaruh signifikan dengan terjadinya manajemen laba untuk menghindari rugi, namun arah koefisien beta yang negatif tidak sesuai dengan arah yang dihipotesiskan yaitu positif. Hasil ini berarti semakin besar pelaporan beban pajak tangguhan justru menurunkan keterjadian manajemen laba untuk menghindari kerugian. Hasil ini sejalan dengan statistik deskriptif yang menyatakan bahwa perusahaan yang menghindari kerugian sehingga berusaha memperoleh laba walau sedikit (small profit), justru terbukti membukukan beban pajak tangguhan lebih kecil dibanding perusahaan yang benar-benar menderita kerugian (small loss).

Beban pajak tangguhan muncul saat laba fiskal lebih kecil daripada laba akuntansi, sehingga pajak yang dibayar dan dilaporkan kepada pemerintah lebih kecil dari beban pajak yang tercatat oleh akuntansi. Peningkatan laba akuntansi melalui manajemen laba yang tidak diimbangi denga peningkatan laba fiskal akan menimbulkan beban pajak tangguhan menjadi lebih tinggi. Laba akuntansi yang dimanipulasi disini ialah laba sebelum pajak. Apabila laba sebelum pajak sengaja dinaikkan oleh manajemen perusahaan tanpa diimbangi dengan peningkatan laba fiskal, maka menyebabkan beban pajak tangguhan menjadi tinggi. Pada saat menyusun laporan laba rugi, beban pajak tangguhan yang meningkat ditambah dengan komponen pajak kini akan memperoleh nilai akun beban pajak yang meningkat. Beban pajak yang sudah meningkat ini digunakan untuk mengurangi laba sebelum pajak sehingga menghasilkan laba yang hanya sedikit atau bahkan rugi. Oleh karena itu, semakin tinggi beban pajak tangguhan yang terjadi maka akan semakin tinggi akun beban pajak yang dilaporkan, menyebabkan laba yang dibukukan oleh perusahaan hanya sedikit atau bahkan rugi. Sehingga dapat disimpulkan bahwa beban pajak yang tinggi justru mengindikasikan perusahaan 


\section{Nominal: Barometer Riset Akuntansi dan Manajemen}

P-ISSN: 2303-2065 E-ISSN: 2502-5430

Volume 9 No 1 (2020)

membukukan rugi. Hasil H1 tidak mendukung temuan Phillips et al. (2003) dan Yuliati (2005).

Hasil pengujian hipotesis kedua menunjukkan kualitas akrual pajak berpengaruh signifikan dengan terjadinya manajemen laba untuk menghindari rugi, dengan arah yang sesuai dengan prediksi yaitu negatif. Penelitian ini berhasil membuktikan bahwa semakin tinggi kualitas akrual pajak penghasilan yang digambarkan dengan semakin rendah variasi (estimation error) yang timbul, menunjukkan rendahnya tingkat keterjadian manajemen laba dalam perusahaan yang ingin menghindari kerugian.

Berdasarkan pengujian dua hipotesis penelitian dapat dibuktikan secara empiris bahwa terdapat perbedaan kemampuan antara beban pajak tangguhan dan kualitas akrual pajak dalam mendeteksi terjadinya manajemen laba. Kualitas akrual pajak lebih superior dalam pendeteksian keterjadian manajemen laba untuk menghindari kerugian. Hasil ini dapat disimpulkan karena $\mathrm{H} 1$ tidak terdukung, sedangkan $\mathrm{H} 2$ terdukung. Selain itu dapat dilihat juga dari nilai koefisien beta. Nilai beta untuk variabel kualitas pajak $(-132,814)$ lebih tinggi dibanding nilai beta variabel beban pajak tangguhan $(-310,245)$. Hasil ini membuktikan bahwa penelitian memberi tambahan kontribusi bagi ilmu pengetahuan yaitu adanya alat selain beban pajak tangguhan untuk mendeteksi manajemen laba untuk menghindari kerugian, yaitu kualitas akrual pajak, khususnya pajak penghasilan.

\section{SIMPULAN DAN SARAN}

\section{Simpulan}

Penelitian ini bertujuan untuk menemukan bukti empiris bahwa beban pajak tangguhan dan kualitas akrual pajak berpengaruh terhadap terjadinya manajemen laba untuk menghindari kerugian. Hasil penelitian menemukan bukti:

(1) Beban pajak tangguhan menurunkan keterjadian manajemen laba untuk menghindari kerugian. Semakin tinggi beban pajak tangguhan yang dibukukan dalam laporan laba rugi suatu perusahaan, maka semakin rendah kemungkinan perusahaan melakukan manajemen laba untuk menghindari kerugian.

(2) Kualitas akrual pajak pajak menurunkan keterjadian manajemen laba untuk menghindari kerugian. Semakin tinggi kualitas akrual pajak penghasilan suatu perusahaan, maka semakin rendah kemungkinan perusahaan melakukan manajemen laba untuk menghindari kerugian.

(3) Kemampuan kualitas akrual pajak dalam pendeteksian keterjadian 
manajemen laba untuk menghindari kerugian lebih superior dibanding beban pajak tangguhan.

\section{Keterbatasan Penelitian}

Penelitian ini memiliki keterbatasan, yaitu pengukuran manajemen laba untuk menghindari kerugian (variabel EM) memiliki range yang terbatas sesuai dengan penelitian terdahulu. Hal ini menyebabkan hanya sedikit sampel yang memenuhi syarat.

\section{Saran}

Berdasarkan keterbatasan penelitian di atas, diajukan beberapa saran sebagai berikut:

a. Untuk Perusahaan, hendaknya mempublikasikan informasi terkait pajak secara rinci dan transaparan dalam pelaporan keuangan agar dapat digunakan oleh stakeholder untuk mengambil keputusan.

b. Untuk Peneliti selanjutnya, hendaknya menelaah lebih banyak literatur supaya memperoleh alternatif pengukuran manajemen laba untuk menghindari kerugian, supaya dapat memperoleh sampel yang lebih banyak.

c. Untuk Peneliti selanjutnya, hendaknya menguji variabel book tax difference sebagai pengganti variabel beban pajak tangguhan, kemudian dibandingkan dengan kualitas akrual pajak.

\section{DAFTAR PUSTAKA}

Burgstahler, D. and Dichev, I. (1997). Earnings management to avoid earnings decrases and losses. Journal of Accounting and Economics,24, 99- 126.

Choudhary, P.; Koester, A. \& Shevlin, T. (2016). Measuring Income Tax Accrual Quality. Review of Accounting Studies, 21(1),89-139.

Dechow, P. M., and Dichev, I. D. (2002). The Quality of Accruals and Earnings: The Role of Accrual Estimation Errors. The Accounting Review,77, 35-59.

Francis,J.,LaFond,R.,Olsson,P.,\& Schipper, K. (2005). The market Pricing of Accruals Quality. Journal of Accounting and Economics,39,295-327.

Healy, P. M., \& Wahlen, J. M. (1999). A Review of the Earnings Management Literature and Its Implications for Standard Setting. Accounting Horizon, 13(4), 365-383.

Holland,D.,Ramsay,A.(2003). Do Australian companies manage earnings to meet simple earnings benchmarks? Accounting and Finance, 43,41-62.

Ikatan Akuntan Indonesia. (2014). Standar Akuntansi Keuangan Per Efektif 1 Januari 2015. Jakarta: Dewan Standar Akuntansi Keuangan Ikatan Akuntan Indonesia.

Phillips,J.,Pincus,M., \& Rego, S. O. (2003). Earnings Management: New Evidence Based on Deferred Tax Expense. The Accounting Review, 78(2),491-521.

Roychowdhury,S.(2006). Earnings Management Through Real Activities 
Nominal: Barometer Riset Akuntansi dan Manajemen

P-ISSN: 2303-2065 E-ISSN: 2502-5430

Volume 9 No 1 (2020)

Manipulation.Journal of Accounting and Economics,42,335-370.

Sumomba, C. R,\&Hutomo,YB.S. (2012). Pengaruh Beban Pajak Tangguhan dan Perencanaan Pajak Terhadap Manajamen Laba. Kinerja,16(2),103115.

Suranggane, Zulaikha. (2007). Analisis Aktiva Pajak Tangguhan dan Akrual Sebagai Prediktor Manajemen Laba: Kajian Empiris pada Perusahaan Manufaktur yang Terdaftar di BEJ. Jurnal Akuntansi dan Keuangan Indonesia,4(1),77-94.

Undang-undang No. 36 Tahun 2008 tentang Pajak Penghasilan.

Waluyo. (2012). Akuntansi Pajak. Jakarta: Salemba Empat.

Yuliati. (2005). “Kemampuan Beban Pajak Tangguhan dalam Memprediksi Manajemen Laba". Jurnal Akuntansi dan Keuangan Indonesia, 2(1),107-129.

www.idx.co.id 